\title{
DETERMINANT OF FACTORS, INFLUENCING LOW ENROLLMENT IN PRIMARY EDUCATION: AN EMPIRICAL ANALYSIS
}

\author{
Muhammad Shahzad Ashfaq, Ph.D (Education) Scholar \\ Department of Education, University of Sargodha, Pakistan.
}

DOI: 10.46609/IJSSER.2020.v05i07.013 URL: https://doi.org/10.46609/IJSSER.2020.v05i07.013

\begin{abstract}
Education is a basic fundamental individual right, enshrined in the Universal Declaration of Human Rights and the United Nations Convention on the Constitutional Rights of the Child. These treaties determine the entitlement of free, obligatory primary education for all children. The present study was conducted to an empirical analysis of factors influencing low rate enrollment in primary education in rural areas. It was a descriptive survey research design study. The population of the study was all the public primary schools located in the rural areas of district Sargodha. A multistage sampling technique was used to select the sample of the study. At the first stage, purposive sampling technique was used to select the primary level public schools, at the second stage, through convenient sampling technique, two hundred primary level schools, heads and teachers were selected. For the gathering of data and information, the researcher developed two comprehensive standardized questionnaires that contained fifty statements. The researcher personally approached to respondents for the collection of data through face to face interview. Pilot testing of the instrument was also conducted. Validity was determined through an expert's opinion and reliability through Cronbach Alpha. The quantitative data were analyzed through SPSS 21. The empirical finding shows parental poverty, illiteracy, unawareness of educational importance, unemployment and migration are the main factors influencing the low rate enrollment in rural areas. Besides the affirmative effect a number of the distinctiveness of individuals, there are several stronger qualitative factors such as socio-cultural and socioeconomic. The government should offer financial support for parents to encourage them to send their children to school this may help in improving the low rate enrollment in primary schooling in rural areas. Some legislative measures should also be implemented to make it necessary for all the parents to complete the primary school education of their children.
\end{abstract}

Keywords: Primary education, school enrollment, socio-cultural factor, parental poverty, socioeconomic factors. 


\section{International Journal of Social Science and Economic Research}

ISSN: $2455-8834$

Volume: 05, Issue: 07 "July 2020"

\section{INTRODUCTION}

Each studying procedure starts evolved with the child's birth. It begins at domestic through copying the elders and monitoring their activities. Although child examine a variety of fundamental abilities in a home, but child have to study more to face the complexity of life and institutions, mainly education, is one of the best aspects of its development. The school is the first stage of a person's society that helps develop some of the competencies in society.

The significance of education, particularly schooling in growing countries, such as Pakistan, has targeted 2.A the cause of the MDGs to make certain through 2015, youngsters in all places will be capable to entire primary education (CRPRID, 2006), and article 28 of the Convention, the UN Convention on the Rights of the Child. In particular: To promote non- obligatory primary schooling and is handy to all to inspire exclusive types of secondary education, which includes vocational and popular education, and to make it available. And give every infant and excellent motion for free education and also to grant monetary assistance, if necessary, take motion on monitoring to inspire normal find out about and limit faculty dropout costs (UN 1989), lack of schools and societies, and this pair of cultural norms play a necessary role in maintaining children away from school and leading, there is less enrollment. Also, due to the extraordinarily small quantity of authorities spending and extend in the percentage of poverty, there is a limit in enrollment in schools. Leaving school influences parents' selections and most of them have their income. Children do no longer make their options independently, however under control, structured on their parents. Its parental tools make bigger based totally on the number of children, the kid's human capital, and the fee of family income and product components, earnings, and time constraints on household contributors and the functions produced (Becker and Lewis, 1973). Presentation of Pakistan in enrollment in primary schools is much less than satisfied, and if these traits continue because there is evidence that the state of affairs is deteriorating, Pakistan will prepare the 2nd region amongst the kids from school. Learn after Nigeria in 2015 (according to Education for All Review 2009). The file concludes that Pakistan and Nigeria are in terrible structure in terms of education, which is accountable for limiting the boom and maintaining millions of children out of school.

Edification is a responsibility for a man or woman care. Education performs a central function in the upward thrust and fall of the nation, especially in the twenty-first century. This is due to the fact of the emergence of international antagonism in training and technology. Information technological know-how is built-in into the core of education. Pakistan is struggling to meet the academic desires of 132 million people. Education is essential for growing nations and empowering human beings to put together them for the expertise and give them the self-belief to compete and reap together advisable goals. Education will increase literacy ranges that make 


\section{International Journal of Social Science and Economic Research}

ISSN: $2455-8834$

Volume: 05, Issue: 07 "July 2020"

contributions to labor productivity and the sustainability of financial development. Education has a notable contribution to rural development. Pakistan is one of the international locations with low literacy costs and nearly half of the population can no longer go to all levels. Pakistan's literacy charge is almost 55\% in 2012-13 (Wasti, 2012). Although Pakistan's literacy charge has risen from $52 \%$ to $60 \%$, literacy charges are now not adequate to compete with the tech world in the closing decade (Editorial, 2013). According to Bokova's document (2015), Pakistan ranked (One Hundred and Thirty-Fifth) amongst growing countries, with solely $49.9 \%$. Education around the world is considered as a characteristic of financial and social development. This is an aid in the Constitution of Pakistan to supply free and basic training to all adolescents between a long time of 5 and 16 and to expand literacy among adults. The study refers to rural areas in Sargodha, Pakistan; the place has been influenced through a weak academic system. Since independence, there has been no substantial alternate in the schooling system, especially in the important education sector. As a result, the country is at the lowest stage of literacy in the region. Pakistani literacy is much less than 50\% (Ahmad, et al., 2013). Developing countries, such as the United States, are analyzing to spend on man or woman education, greater than they did in the past. As the distinction between growing countries, the education state of affairs in Pakistan is not so encouraging due to the fact of the major reasons for poverty and the altering financial scenario in the country. The wide array of academic budgets is spent on revenue and is no longer affordable on enhancing qualifications such as teacher training, the growing variety of schools, and supervision. For this purpose, extra funds must be allocated. The NER (the net enrollment ratio) at the primary level shows that we are some distance from government targets. The institutions will a work higher and greater success when an administrator has proper and decision-making rights. The most developed nations have been registered for registration, which includes growing nations such as Albania, Argentina, Chile, Mexico, Russia, and different countries (Heredia, 2007). The Sargodha district used to be chosen for poverty and people's livelihood. The Sargodha district covers a vicinity of 6270 square kilometers, in accordance with the Sargodha population census in 1998, 1,296,304, and eighty-four percent in rural areas. The literacy rate in Sargodha in 1998 used to be $24.63 \%$ (male $35.01 \%$, woman $12.9 \%$ ). Primary school is $65 \%$, while $33 \%$ have carried out major schooling (PSLM 2014-15). Public and nonpublic educational institutions are working hard to enlarge the range of enrolled students and minimize the percentage of dropouts in surveyed areas.

Regarding Pakistani record, it is behind the history in the back of the South Asian nations for Regional Cooperation (SAARC). There are several causes for enrollment costs and the lower literacy ratio in Pakistan. Particular of the primary limitations of the way of education and capital mobilization in Pakistan is poverty, insufficient funds for public schools, lack of primary infrastructure, high inflation, and the low value of education, masculinity inequality, and poverty. The public and non-public schools in the region, inequality, lack of certified teachers 


\section{International Journal of Social Science and Economic Research}

ISSN: $2455-8834$

Volume: 05, Issue: 07 "July 2020"

and resources, excessive school charges, bad non-public educational plans and their execution, etc. Ahmad, et al., (2013), Baluch and Shahid (2008), Toor and Parveen, (2004), Alderman, (2001); existing literature highlights numerous elements that affect institute enrollment selections and the femininity gap in schooling in Pakistan. There are two hypotheses about the association between edification and poverty. One of these was frequent by using Afzal et al. (2010); Chaudhry and Rahman (2009); Njong, (2010), schooling that will increase employment possibilities and progressive development, in flip performs a vital function in poverty reduction. Another factor is that poverty is the foremost cause adolescents are no longer enrolled or dropped out of school earlier than they complete primary education. Poor households have no longer been capable to pay, for school uniforms, shoes, transport, books, and stationery. Even though the government gives free books, uniforms, etc. At the onset, the value of attending a choice school is excessive for a terrible family in contrast to two children belonging to non-poor households. That's why children belonging to poor families who are no longer enrolled in the school and be a part of the labor market to assist their families (Arif Effort, et al., 1999).

Education contribution to financial improvement is well-known. The contribution of education to the economic increase has been effective and giant not only in financial conditions, however additionally in physical conditions, farm efficiency, and labor productivity. It has additionally been determined that schooling is a vital aspect of poverty reduction, enhancing earnings distribution and dimensions of social, demographic, and political development. Considering education as a key device for mobilizing human capital for sustainable socio-economic growth, the government is concerned in developing and imposing policies, development, and enhancement of the education system to accommodate the desires of the country.

\section{LITERATURE REVIEW}

School enrollment has been mentioned in countless instances at countrywide and global levels. The previous research studies examined exceptional variables and a combination of variables to decide their effect and editions over the years. Increasing the variety of students enrolled in primary schools is usually a precedence for the government. This problem has been controversial in every session and suitable measures have been proposed and carried out in every regime. This is the most important trouble for most growing countries. Data from the time sequence used government low rate index. The authorities spending, less on the labor force, and healthcare expenses. The consequences confirmed an effective affiliation of labor costs, government and health care with enrollments at all levels of leasing in Pakistan, and the patron fee index and the government's return on revenues to report levels. The same enrolled students can't be detained, despite several plans and struggles of the administration. The educational authorities have shown weaknesses to improve primary schooling in Pakistan, poverty, and different social and cultural 


\section{International Journal of Social Science and Economic Research}

ISSN: $2455-8834$

Volume: 05, Issue: 07 "July 2020"

factors.

Numerous research studies had been carried out over the previous two decades, the economic factors that have influenced school enrollment, but the impact of social and cultural elements on enrollment / abandonment in Primary education in the context of the district Sargodha, which has not often seen. In the equal length of time, there are many dimensions as described by way of studies, people's education that has added about fine adjustments of social problems such as terrorism, infant labor, and different crimes by using reduce poverty when people can no longer meet their simple needs of existence as a crime. To acquire whatever, they desire described by Fabre and Augersaud-Veron, (2004), Kruger and Maleckova, (2003). According to the National Education Committee's document (Lynd, 2007), 31\% of students enrolled in a non-public academic organization that received primary education in urban areas of Pakistan. Many elements are influencing gaining knowledge of students in schools employing qualified and skilled teachers, preparation to students, teachers, physical places (school infrastructure), student potential, and socioeconomic background. The findings advocate that enrollment of children in schools is delayed and greater serious for girls and gender inequality. The school's most important consideration will increase the share of children's universal education and further influence the boy's education and it's necessary for schoolgirls. Parenting additionally enhances education for children. Higher family earnings and property possession increase the possibility of attending school.

\section{The Primary Enrollment}

The dimensions of high-quality school get access or availability, and the effect they have to work to enlarge enrollment even although the effect is small and different by using gender. The traits of people and families are for sure the most essential determinants of enrollment at a special school for girls. The chance of the growing enrollment in mother or father education, such as the mother's education, is necessary for encouraging enrollment of the girl. The study additionally emphasized the significance of some rural context impacts. The National Education Policy (2009) was once originally set up through the truth that pre-policy (1998-2010) did not deal with; it delays in education and output in phrases of enhancing key indicators stop. Second, we understand that global commitments and challenges by way of the Jomtien, the Millennium Development Goals and the Urban Action Framework, education for all that can be overcome by way of reconsidering the policy Globalization and inserting stress on the transfer. This policy focuses on the want for superior public-private partnerships, encouraging education accuracy, and restoring self-assurance in education in the public sector. The policy paper tested the management's dedication to accomplishing the UPE 2015 through enhancing provision delivery and offering superior roles for regional and local governments to tackle these matters. National 


\section{International Journal of Social Science and Economic Research}

ISSN: $2455-8834$

Volume: 05, Issue: 07 "July 2020"

Education Policy (2009) consists of a complete framework to execute and emphasis on cooperation between the federal and provincial governments.

In the research study, Haneda (1999) pointed out that the growing enrollment at primary schools is simpler than doing. The significance of "schooling" elements in schooling closer to family consumption remains controversial and has a devastating effect on education policy. The authors of Rana and Karamat (2003) cited that Pakistan stays a country the place most education policies and plans do not play the main function in increasing knowledge. The authors of Basilius and Anak (2017) are analyzing the growth and schooling system for the negative in Pakistan. Hameed and Sewani (2013) describe that the political and home education policies in Pakistan, consolidate international coverage want to be improved. The authors Majoka and Khan (2017) focus on four main political and educational structures in the United States of America - higher education, intermediate education, primary education, and vocational and technical education since 1947. Many activities, the center of attention on keeping the community and associated education (Nasir and Nazli, 2000). Nonetheless, the author of Memon (2007) says that education performs an essential function in society and has a close connection between education and development. The writers in Hameed and Sewani (2013) are gaining knowledge of political, and home education policies in Pakistan. Policies to consolidate international policy want to be improved. This study indicates necessary issues. In the procedure of growing its policies and practices at all tiers of education in Pakistan.

\section{Gender Disparities}

The evaluation of this topic, in addition to the preceding update, goes to many categories; add context, techniques, and facts, used to learn about the determinants of enrollment in primary schools. While analyzing whether or not, there is a gender disparity due to inadequate funding in women's education, or due to the fact of decrease returns on education. Grace (2012) reviews that the most chance of the likelihood of Logit is being enrolled in schools, the use of Pakistan Social and Living Standard Assessment (PSLMS) 2005-06. In another study, Gessie et al (2014) examined the determinants of a chance of being enrolled in schools in the context of the broader vary of child inclusion / options for families. The school enrollment scores are primarily based on the 2010 Pakistani family survey. The function of women in the education of children in the family's interest in attracting Pakistan. Hamid (1993) used a simple analysis to decide the proportion of families that sent their children to school is excessive, with the headwoman the same to different families. Maitra and Ray (2000) grant logic, multi-variable options, schools, and / or jobs primarily based on facts from PIHS, 1991. There is a gender gap in the kid's literacy. It has a profound effect on the education of kids and the hassle of female learning. Maternal education has a considerable effect on improved enrollment at schools. Children from 
International Journal of Social Science and Economic Research

ISSN: $2455-8834$

Volume: 05, Issue: 07 "July 2020"

families with children under 15 are much less likely. It has been found that the contribution of women's education is excessive in urban areas, comparing to rural areas. Women's schooling, the contribution is greater in urban areas compared to rural areas. It is estimated that more than 50\% of women fall out due to low exceptional education and the fact that this school is not a giant team of people they serve. To obtain gender equality it is imperative to make a bigger public expenditure. We want the dedication to growing instructional structures and different devoid structures of preconceptions of gender.

\section{Socio-Cultural}

Although the focus of Sathar, et al. (2013) the impact of gender poverty and access to secondary schools for girls in Pakistan, the existing a thorough evaluation of the net enrollment of primary schools for the female primarily based on information from PSLMS. Also, they estimate that there are models of transportation regression to estimate the coefficients for females attending school. In another study, Gessie, et al., (2014) examined the determinants of the likelihood of being enrolled in schools in the context of the broader vary of child inclusion / solutions for families. The proportion of girls is quite low, especially in rural areas of Pakistan; for example, in Sindh and Baluchistan, where the literacy rates for girls are 23 percent and 16 percent (Lynd, 2007).

\section{Socio-Economic}

Karanu, et al., (2015) examined socioeconomic, social, cultural and financial factors affecting enrollment in primary schools in Kenya as it observed that economic, social, cultural and financial influences that had a sizeable effect on the rate of enrollment and have brought on mother and father no longer to enroll their children in primary school and to withdraw from primary school earlier than complete. Babatunde \& Adefabi (2005), Education with financial goals, alongside with many different purposes, education has a positive impact on the financial progress of every society and growing occupation chances, accelerated health care services, decreased stages of poverty and enhancement of technological development and political stability. Investments in education are crucial for the development of nations. On the one hand, education boosts economic increase, on the other hand, supporting to minimize poverty by growing productiveness (Support is Afzal, et al., 2012).

\section{Parental Education}

The Determination of Child Registration Studies (Nadeem A. Burney, 1995) makes use of a regression evaluation and concludes that family earnings and parenting have an advantageous relationship with child registration. Aakvik, et al., (2005) examined the effect of a family's 


\section{International Journal of Social Science and Economic Research}

ISSN: $2455-8834$

Volume: 05, Issue: 07 "July 2020"

perspective, such as family earnings and educated parents on the education tiers of people born from 1967 to 1972 in Norway. OLS requirements are utilized to calculate variable- based estimates, relying on the degree of personalized education and unbiased variables, such as family income, education, household, and maternity expenses. Self-educated parents are capable to make investments in the schooling of their children (Alderman et al., 1996). There is a robust relationship between parenting and parenting solutions (Ravallion and Wodon, 2000). Children of higher educated parents have fewer possibilities to drop out of school than children with loweducated or uneducated parents. Parental qualifications, family size, teacher guidance, and school affinities have an impact on pupil success (Saeed, et al., 2005).

\section{Poverty of Parents}

The dedication of rural school education in Pakistan (Ali, 1999), in this literature, is recorded and investigated the definitions of the education of the kids as a whole and as awesome girls and men use the fundamental statistics for rural households. Factors such as poverty and enrollment in gender, most important schools in Pakistan (G.M Arif struggles in 1999). The document shows that poverty has a great poor impact on enrollment in essential schools, and if there is an increase, earnings will increase enrollment in schools. The writer Moulton (2001), describing his poverty-stricken study, can be eradicated through rural education and can enhance the strategy of agriculture, higher utilization of resources, and eventually improved performance.

The author Khuwaja et al., (2005) explores essential elements and emphasizes rural education in Pakistan. Mediation needs the focal point on family education with more efforts to minimize poverty. Better perception is wished to focus on improving health, education, and obstetrics. The author Rahman Chaudhry (2009) observed the important influence of femininity disparity in schooling in phrases of rural poverty in Pakistan. It indicates that masculinity difference in schooling influences rural poverty. Women's education is quintessential in decreasing poverty. Another learns about the best rate of enrollment in Pakistan (Farrukh, and Bayesh, 2011) discovered macroeconomic variables at exceptional levels, primary schools, secondary schools, colleges, and universities in Pakistan.

\section{Teacher Education}

Education governance is the accountability of the federal authorities and interim, previous governments have given regional strength for implementation and organization. A. Abro, M.Y. Jamali and G. F. Laghari, (2013) mentioned that stakeholders are fully responsible for this. 80\% of parents blame educators and personnel for excessive dropout rates. They declare that the teacher's common mind-set and the bad track document of educators have led adolescents to depart school. $89 \%$ of teachers agree that their parents do no longer have a little knowledge, their 


\section{International Journal of Social Science and Economic Research}

ISSN: $2455-8834$

Volume: 05, Issue: 07 "July 2020"

children's education, which causes teens to leave school completely rather have parents like their children to earn cash instead than school. $67 \%$ of educational personnel say teachers and parents are equally accountable for dividing excessive school students, resulting in high dropout rates. 98\% of students recognize that parents, teachers, and educational staff have no longer opted for students who have dropped out of school.

The authors of Aithal and Shubhrajyotsna (2016) argue that primary schooling at the main stage is regular with the brick and mortar buying and selling system place students are systematically educated. However, the easy education system has many weaknesses and many expectations are anticipated in the future. The satisfaction of teachers' work is of paramount importance and at once influences the academic fulfillment of their future students and careers.

\section{School Facilities}

An author Lin (2007) briefed the Pakistani schooling system. His study focuses on the main education system, and it is cautiously viewed the potential and contribution to the schooling of the nation and non-public institutions. There are additionally short speeches about school management, their best of work, and their devotion. These learn about covers school facilities, assistants, instructing modules, and planning management. The authors argue that Pakistan is progressing poorly in the direction of the Millennium Development Goal, which relates to teaching all children. It has been mentioned that greater than $50 \%$ of the female have dropped out of school due to the terrible quality of training and the reality that schools are no longer sufficient for the group they serve. The share of the female is extraordinarily low, especially for parts of Pakistan, for example, in Sindh and Baluchistan, the place literacy quotes for the female are twenty three percent and sixteen percent (Lynd, 2007).

It has been observed that the contribution of women's education is excessive in city areas, comparing to rural areas. It is estimated that greater than $55 \%$ of the female fall out due to the low quality of teaching and the reality that these schools are no longer a large crew of human beings they serve. Nonetheless, the author of Memon (2007) says that education performs a necessary function in society and has a shut connection between education and development. Educational establishments enhance the economic, political, social, and cultural existence of the nation.

\section{METHODOLOGY}

The descriptive survey method was used for the study. The population of the study was all the school's heads and teachers of public primary schools in rural areas of district Sargodha. A multistage sampling technique was used to select the sample of the study. In the first step, the 
researcher used a purposive sampling technique to select public primary schools in rural areas, on the second step; a convenient sample technique was used for semi-structured interview protocol of school's heads and teachers. The sample was comprised of two hundred public primary institute's heads and educators. Two research questionnaires were used for the collection of data. Each question was on the five points Likert scale. Pilot testing of the instrument was also conducted. The researcher personally approached respondents and data was gathered through face to face meetings. The statistical package of social science was used to analyze the collected data. Validity was determined through an expert's opinion and reliability through Cronbach Alpha.

\begin{tabular}{|cl|c|c|}
\hline \multicolumn{3}{|c|}{ Case Processing Summary } \\
\hline & & $\mathbf{N}$ & $\%$ \\
\hline \multirow{2}{*}{ Cases } & Valid $^{2}$ & 200 & 100.0 \\
& Excluded $^{\mathrm{a}}$ & 0 & .0 \\
& Total & 200 & 100.0 \\
\hline
\end{tabular}

\begin{tabular}{|c|c|}
\hline \multicolumn{2}{|c|}{ Reliability Statistics } \\
\hline Cronbach's Alpha & N of Items \\
\hline .815 & 50 \\
\hline
\end{tabular}

\section{DATA ANALYSIS AND INTERPRETATION}

Table 01: Responses in Teachers Education

\begin{tabular}{|c|l|c|c|c|c|c|}
\hline S.No & \multicolumn{1}{|c|}{ Statements } & Mean & SD & df & \multicolumn{2}{|c|}{ Chi-Square } \\
\cline { 5 - 7 } & & & & & $\chi^{2}$ & Sig \\
\hline 1 & Educators in your institute are well qualified & 2.03 & .792 & 4 & 230.25 & .000 \\
\hline 2 & $\begin{array}{l}\text { Teachers in your school are professionally well- } \\
\text { trained }\end{array}$ & 2.85 & 1.377 & 4 & 12.40 & .015 \\
\hline 3 & $\begin{array}{l}\text { The selection procedure for the recruitment of } \\
\text { teachers is standardized }\end{array}$ & 2.66 & 1.146 & 4 & 47.65 & .000 \\
\hline 4 & Professional training is providing to educators & 3.01 & 1.270 & 4 & 14.00 & .007 \\
\hline 5 & $\begin{array}{l}\text { The teacher communicates the subject matter } \\
\text { effectively in the class }\end{array}$ & 2.83 & 1.282 & 4 & 31.65 & .000 \\
\hline 6 & Educators have expertise above subject matter & 2.51 & 1.256 & 4 & 31.00 & .000 \\
\hline 7 & $\begin{array}{l}\text { Educators have a grasp over instruction } \\
\text { methodology }\end{array}$ & 2.78 & 1.277 & 4 & 19.25 & .001 \\
\hline 8 & $\begin{array}{l}\text { Educators maintaining an atmosphere that is } \\
\text { conducive to learning }\end{array}$ & 2.70 & 1.200 & 4 & 35.75 & .000 \\
\hline 9 & The teachers arrive on time. & 2.88 & 1.282 & 4 & 12.75 & .013 \\
\hline
\end{tabular}


International Journal of Social Science and Economic Research

ISSN: $2455-8834$

Volume: 05, Issue: 07 "July 2020"

\begin{tabular}{l|l}
\hline 10 & Incentives are prearranged for inspiration of
\end{tabular} worthy educators

2.77

1.322

4

10.15

.038

Analysis of the findings in the Table 1 shows that the value of ten statements of Chi-square $\chi^{2}$ $(\mathrm{df}=4)=230.25,47.65,35.75,31.65,31.00,19.25,14.00,12.75,12.40$, and 10.15. The values of Chi-square of these statements are much higher than the critical values $\chi^{2}(\mathrm{df}=4)=$ 9.48 at $a=0.05$. Means of these statements with standard deviation show that these are more than the midpoint of distribution and in the right direction. It means that ten statements related to "teacher's education" are highly accepted.

Table 02: Responses in Teaching Methodology

\begin{tabular}{|c|l|c|c|c|c|c|}
\hline S.No & \multicolumn{1}{|c|}{ Statements } & Mean & SD & df & \multicolumn{2}{|c|}{ Chi-Square } \\
\cline { 5 - 7 } & & & & & $\chi^{2}$ & Sig \\
\hline 11 & $\begin{array}{l}\text { Subjects and content being taught are relevant to } \\
\text { the present and future needs of society. }\end{array}$ & 2.64 & 1.253 & 4 & 20.15 & .000 \\
\hline 12 & $\begin{array}{l}\text { The syllabus being educated at school is } \\
\text { according to the increasing needs of society. }\end{array}$ & 2.46 & 1.036 & 4 & 116.85 & .000 \\
\hline 13 & $\begin{array}{l}\text { Your school emphases upon a qualitative aspect } \\
\text { of education }\end{array}$ & 2.50 & 1.089 & 4 & 113.35 & .000 \\
\hline 14 & $\begin{array}{l}\text { Religious consciences are continued at the } \\
\text { institute }\end{array}$ & 2.93 & 1.228 & 4 & 36.35 & .000 \\
\hline 15 & $\begin{array}{l}\text { Devotion is given to the character-building of } \\
\text { learners }\end{array}$ & 2.51 & 1.156 & 4 & 49.85 & .000 \\
\hline 16 & Innovative thinking is fortified in class. & 2.72 & 1.261 & 4 & 20.95 & .000 \\
\hline 17 & $\begin{array}{l}\text { The school atmosphere is appropriate for } \\
\text { instruction. }\end{array}$ & 2.67 & 1.122 & 4 & 68.45 & .000 \\
\hline 18 & Instructional facilities are appropriate. & 2.91 & 1.238 & 4 & 19.65 & .001 \\
\hline 19 & The educators are capable of usage A.V aids. & 2.80 & 1.211 & 4 & 25.00 & .000 \\
\hline 20 & Educators use A.V. aids professionally & 2.84 & 1.217 & 4 & 33.40 & .000 \\
\hline 21 & Professional safety for educators is ensured & 2.67 & 1.232 & 4 & 21.95 & .000 \\
\hline
\end{tabular}

The findings in the Table 2 shows that the value of eleven statements of Chi-square $\chi^{2} \quad(\mathrm{df}=4)=$ $116.85,113.35,68.45,49.85,36.35,33.40,25.00,21.95,20.95,20.15$ and 19.65. The values of Chi-square of these statements are much higher than the critical values $\chi^{2}$ $(\mathrm{df}=4)=9.48$ at $\mathrm{a}=0.05$. Means of these statements with standard deviation show that these are more than the midpoint of distribution and in the right direction. It illustrates that most of the respondents accepted these statements related to teaching methodology. 
International Journal of Social Science and Economic Research

ISSN: $2455-8834$

Volume: 05, Issue: 07 "July 2020"

Table 03: Responses in Primary Enrollment

\begin{tabular}{|c|l|l|l|l|l|l|}
\hline S.No & \multicolumn{1}{|c|}{ Statements } & Mean & SD & df & \multicolumn{2}{|c|}{ Chi-Square } \\
\cline { 5 - 7 } & & & & & $\chi^{2}$ & Sig \\
\hline 22 & Students are admitted according to merits & 2.77 & 1.207 & 4 & 26.25 & .000 \\
\hline 23 & The student assessment procedure is fair & 3.07 & 1.156 & 4 & 41.95 & .000 \\
\hline 24 & The student-teacher ratio is adequate & 3.29 & 1.262 & 4 & 20.35 & .000 \\
\hline 25 & Merit is strictly followed in all matters. & 3.22 & 1.224 & 4 & 22.45 & .000 \\
\hline 26 & Questioning is encouraged in class. & 2.78 & 1.139 & 4 & 78.80 & .000 \\
\hline 27 & Your school provides quality education & 3.29 & 1.137 & 4 & 49.07 & .000 \\
\hline 28 & Co-curricular events are organized frequently. & 2.78 & 1.127 & 4 & 59.15 & .000 \\
\hline 29 & $\begin{array}{l}\text { Appropriate planning is directed before } \\
\text { launching any activity in the institution. }\end{array}$ & 3.26 & 1.148 & 4 & 116.90 & .000 \\
\hline
\end{tabular}

The result of the findings in the Table 3 shows that the value of eight statements of Chi- square $\chi^{2}(\mathrm{df}=4)=116.90,78.80,59.15,49.07,41.95,26.25,22.45$, and 20.35. The values of Chi-square of these statements are much higher than the critical values $\chi^{2}(\mathrm{df}=4)=9.48$ at a $=0.05$. It indicates that most of the respondents accepted these statements related to primary enrollment.

Means of these statements with standard deviation show that these are more than the midpoint of distribution and in the right direction.

Table 04: Responses in the physical environment and school facilities

\begin{tabular}{|c|l|c|c|c|c|c|}
\hline S.No & \multicolumn{1}{|c|}{ Statements } & Mean & SD & df & \multicolumn{2}{|c|}{ Chi-Square } \\
\cline { 5 - 7 } & & & & & \multicolumn{1}{|c|}{$\chi^{2}$} & Sig \\
\hline 30 & School building facility is adequate & 2.89 & 1.138 & 4 & 59.05 & .000 \\
\hline 31 & $\begin{array}{l}\text { The school has well-maintained the boundary } \\
\text { wall }\end{array}$ & 2.89 & 1.138 & 4 & 59.05 & .000 \\
\hline 32 & $\begin{array}{l}\text { The school has a separate staff room for } \\
\text { teachers }\end{array}$ & 5.00 & .000 & 4 & 200.00 & .000 \\
\hline 33 & The drinking water facility is available & 3.06 & 1.197 & 4 & 30.35 & .000 \\
\hline 34 & $\begin{array}{l}\text { Suitable fans are available in all classrooms of } \\
\text { the school. }\end{array}$ & 3.10 & 1.307 & 4 & 27.65 & .000 \\
\hline 35 & $\begin{array}{l}\text { The gas facility is existing in all classrooms of } \\
\text { the school }\end{array}$ & 5.00 & .000 & 4 & 200.00 & .000 \\
\hline 36 & $\begin{array}{l}\text { Adequate furniture is available in the } \\
\text { classrooms }\end{array}$ & 3.19 & 1.061 & 4 & 83.35 & .000 \\
\hline 37 & $\begin{array}{l}\text { Equipment is according to current and } \\
\text { upcoming needs }\end{array}$ & 3.02 & .974 & 4 & 83.85 & .000 \\
\hline 38 & Required A.V. aids are available. & 2.89 & 1.259 & 4 & 18.10 & .001 \\
\hline 39 & $\begin{array}{l}\text { Supercomputers are available in the computer } \\
\text { laboratory }\end{array}$ & 5.00 & .000 & 4 & 200.00 & .000 \\
\hline
\end{tabular}


International Journal of Social Science and Economic Research

ISSN: 2455-8834

Volume: 05, Issue: 07 "July 2020"

\begin{tabular}{|l|l|l|l|l|l|l|}
\hline 40 & The playground is available for sports. & 3.73 & 1.190 & 4 & 58.15 & .000 \\
\hline
\end{tabular}

Analysis of the findings in the Table 4 shows that the value of eleven statements of Chi- square $\chi^{2}(\mathrm{df}=4)=200.00,200.00,200.00,83.85,83.35,59.05,59.05,58.15,30.35,27.65$ and 18.10 . The values of Chi-square of these statements are much higher than the critical values $\chi^{2}(\mathrm{df}=4)$ $=9.48$ at $\mathrm{a}=0.05$. It illustrates that respondents slightly rejected these statements related to "school facilities". Means of these statements with standard deviation show that these are more than the midpoint of distribution and in the right direction.

Table 05: Responses in Parental Education

\begin{tabular}{|l|l|c|c|c|c|c|}
\hline S.No & \multicolumn{1}{|c|}{ Statements } & Mean & SD & df & \multicolumn{2}{|c|}{ Chi-Square } \\
\cline { 3 - 7 } & & & & & \multicolumn{1}{|c|}{$\chi^{2}$} & Sig \\
\hline 41 & Parents of your area are well-educated & 3.77 & 1.299 & 4 & 77.55 & .000 \\
\hline 42 & Parents are aware of educational importance & 3.60 & 1.334 & 4 & 41.30 & .000 \\
\hline 43 & $\begin{array}{l}\text { Parents are financially sound and well } \\
\text { established }\end{array}$ & 3.90 & 1.080 & 4 & 99.85 & .000 \\
\hline 44 & Parents attend teacher-parent meeting regularly & 3.63 & 1.187 & 4 & 43.80 & .000 \\
\hline 45 & $\begin{array}{l}\text { Parents prefer education of their children than } \\
\text { labour }\end{array}$ & 3.76 & 1.212 & 4 & 58.80 & .000 \\
\hline 46 & Parents attend school when school call them & 3.52 & 1.152 & 4 & 43.15 & .000 \\
\hline 47 & Parents care about their children uniform & 3.75 & 1.223 & 3 & 28.00 & .000 \\
\hline 48 & $\begin{array}{l}\text { Parents check their children's books and bags at } \\
\text { home }\end{array}$ & 3.40 & 1.116 & 4 & 65.00 & .000 \\
\hline 49 & Parent's attitude positive towards public schools & 3.57 & 1.167 & 4 & 43.05 & .000 \\
\hline 50 & Parents are cooperative with public schools & 4.21 & 1.100 & 4 & 176.35 & .000 \\
\hline
\end{tabular}

The findings in the Table 5 shows that the value of nine statements of Chi-square $\chi^{2}(\mathrm{df}=4)=$ $176.35,99.85,77.55,65.00,58.80,43.80,43.15,43.05$, and 41.30. The values of Chi-square of these statements are much higher than the critical values $\chi^{2}(\mathrm{df}=4)=9.48$ at $\mathrm{a}=0.05$. The value of the remaining one statement of Chi-square $\chi^{2}(\mathrm{df}=3)=28.00$. The value of Chi- square of this statement is much higher than the critical values $\chi^{2}(\mathrm{df}=3)=7.81$ at a $=0.05$. It illustrates that most of the respondents rejected these statements related to "parental education".

Means of these statements with standard deviation show that these are more than the midpoint of distribution and in the right direction.

\section{DISCUSSION}

The major focus of the existing learns about is the education sector of Sargodha, Pakistan. It is centered only on a rural place in the district Sargodha. The authorities want to make some 


\section{International Journal of Social Science and Economic Research}

ISSN: $2455-8834$

Volume: 05, Issue: 07 "July 2020"

policies that chiefly center of attention in rural areas. Private institutions have a monopoly in rural areas in offering schooling at actual price cost, so it is difficult for villagers to pay an excessive charge for their children. Due to excessive fees, many teenagers can't get their schooling, and then they reject education and are compelled to do the job at a low wage. Because of these phenomena, child labor is growing in society and return will become the purpose of the increase in illiteracy rate. Rural improvement is essential for Pakistan due to the fact most people live in rural areas. Raising academic ranges of the person individuals of the family and increasing public cognizance can have a giant positive effect on the rural school enrollment.

The goals of this paper are looking at the factors influencing on the main school enrollment in rural areas and seem for motives in the back of never enrolled in school. The different requests and supply-side determining the factor of enrollment in primary education are additionally analyzed. The outcomes assist us to accomplish, that the pupil's characteristic and the parent's characteristic, the vicinity of the residence, the place of residence for getting admission to school are vital causes of enrollment in primary schools in Pakistan. The likelihood of school enrollment is negatively associated with poverty, family size, and distance to the nearest school. Parental education, family asset, age, and gender of the child and vicinity of the house (rural) are positively associated with school enrollment.

This paper ascertains a variety of influences that account for decrease primary enrollment. Some elements are huge from a ruling point of view. Age of youth is one of the extensive factors which positively affect school enrollment. Hence, to increase school enrollment and keep away from late enrollment, management must pay attention to pre-school amenities. Parental poverty is a hurdle in academic attainment. Consequently, strategy makers need to emphasize their interest in the direction of terrible households to extend school enrollment. Recognition and credit accessibility to a deprived family may additionally play a necessary position in improving enrollment in schools. The poor outcome of distance to the nearest school is extra reported in rural areas.

Now awaken of notable developments in knowledge and technology and the emergence of know-how economy, it did not appear viable for a society to grow by $50 \%$ literacy costs and without an exceptional education. The Pakistani administration has to exhibit an excessive stage of political spirit and dedication to create both quantitative and qualitative advancement, not only on basic schooling but additionally greater education. Existing masses of proof, that literacy and primary schooling can be increased with the aid of linking parents, municipal and local organizations in the struggles to improve in this concern. Though, all these desires can accomplish with political steadiness and desirable supremacy. We want to assemble extra schools, in addition to enhancing the current ones. Conferring to the overview of the literature, 
International Journal of Social Science and Economic Research

ISSN: $2455-8834$

Volume: 05, Issue: 07 "July 2020"

we want to emphasize on enrollment, retaining and superiority acquire UPE in Pakistan. Educators need to be selected on merit and remain skilled to encourage thoughtful imagination and imperative questioning amongst the students. The educators need to be educated following the present-day teaching-learning methods. They ought to grant the pupils getting to know the environment and gaining knowledge of skills that motivate their increased contribution to the instruction process. The educators need to additionally be skilled to provide a first-class and an eye-catching gaining knowledge of the surroundings to the pupils to minimize their drip outs. Pakistan has come to be a focus of global political activity in current years. Much growth stays to be made in making sure that children, especially in rural areas of Pakistan is going to school and studying while in school.

\section{CONCLUSION}

The findings of the empirical evaluation are shown that many elements are influencing the low enrollment ratio of primary education in rural areas. The predominant purpose of the collapse of primary education is the lack of governmental interest and the lack of teachers' devotion. Teachers in ordinary and government in precise are accountable for this alarming scenario of primary education in Pakistan. Lack of physical and academic facilities; inadequate certified staff; terrible supervision and management; political interference; negative appointment policies; teachers' absenteeism; unsatisfactory comparison and examination system; poor curricula; ineffective pre-service coaching programs; inadequate finances for education; corruption; no appropriate check and balance system; bad implementation of educational policies; bad discipline; the lack of coordination between schools and community; parental low socioeconomic status; child labor; parental terrible attitudes; illiteracy of parents; and lack of in carrier coaching programs for teaching workforce are the factors that effect on two essential education. Unfortunately, due to lack of interest from the government, the improvement of rural areas is viewed to be unsatisfactory. In the lights of the contemporary study, it is counseled that the government demonstrates desirable interest in the public and non-public education sector in the rural areas which will eventually enlarge the literacy rate, personal growth, and improvement of rural areas.

They learn about additionally concluded that poverty, parents' attitude, lack of school facilities, homework, cultural and regular cause, etc. Are the most important reasons for low enrollment in primary education? It is additionally necessary to create the attention of woman education amongst parents, basically the parents of remote areas. The femininity disparity in schooling has a vast effect on rural poverty. The women enrolment ratio, the male literacy ratio, the femalemale ratio of whole years of education of the populace, education of household head, the femalemale ratio of recipients, the age of household, head, strength retaining, and land preserving are 
International Journal of Social Science and Economic Research

ISSN: 2455-8834

Volume: 05, Issue: 07 "July 2020"

widespread variable taking bad, result on the chance of being poor rural areas. To manage overpopulation, there is a need to re-address populace policies. The government undertakes sustainable improvement techniques for the enhancement of the socioeconomic reputation of trained women.

The poverty of the parents is one of the main reasons for pupil dropout. Consequently, it is endorsed that the management needs to supply free notebooks \& uniforms and month-to- month stipends to needy pupils thus they may also be in a position to proceed with their schooling. Very frequently pupils are dropped out from the institute owing to the fact of a substantial workload at domestic or home chores. This is encouraged that parents have to be explained about the significance and importance of education thus they may also prolong rest to pupils from domestic work throughout school timings. The common absenteeism of pupils from the school, lastly caused by dropout. Subsequently, it is encouraged that educators regularly interact with the parents of pupils and talk about the matter with them. Teacher absenteeism at the primary level has turned out to be a common marvel and this motivates student's dropout. No through the instructional branch furthermore, the parent educator's council be allowed to take a look at teacher absenteeism. Failure and repetition of the same grades of pupils additionally reason a pupil's dropout from schooling.

\section{RECOMMENDATIONS}

1. The existing primary school instructors are educated, skillfully in study room administration, and advanced instructional methodologies.

2. The medium must be English, and the course should comprise applicably contents. Absolute orthodoxy has to be relinquished.

3. The syllabus should be revised and rewritten following the rising necessities of the pupils and contemporary society.

4. An effective look and stability method should be applied effectively. The examination and evaluation system need to be made effective.

5. The teacher- guardian linkage is a wish and the necessity of time. Social interplay with the school would be help full incoming time to make a positive enrollment.

6. The teacher to be given refresher coaching following the present-day needs of time computer, scientific terminologies, global politics, environmental adjustments like objects need to be updated.

7. The education department is to be given prior consideration. A feel of the test and stability wants to be developed. The responsible authorities must attain to the bottom level. The literacy rate of involved aria has to be analyzed through respective school members. 
International Journal of Social Science and Economic Research

ISSN: $2455-8834$

Volume: 05, Issue: 07 "July 2020"

8. Trips and certain other extracurricular things to do should be taken into action. Proper uniform needs to be prescribed for government schools.

9. The government needs to make sure that enough equipment will be given to schools on facilitated school are not greatly welcome through the mass.

10. The school building must be outfitted with water, electrical energy personal computer lab, and library facilitates.

11. The unanimous curriculum will ensure unanimous energy in the respective school of rural area legend needs to be consulted to design the syllabus.

12. Political intervention in education needs to be dispirited.

13. Pupils from poor and financially lower socio-economic background families need to be arranged scholarships thus they can also proceed with their schooling successfully.

14. The main aspect is recommended that complete the society ought to take the query of education with utmost sobriety and eager interest. Let the primary education be given due status in society.

15. There be consistent policy made by using the government to make the education technique, credible sufficient altering, and type attitudes proved time and once more jeopardizes each recognition and credibility.

16. Hence, there is a want to put into effect certain progressive measures to create attention related to the importance of the basic education not only to adopt any income-producing exercise, however, also to understand societal aspirations.

17. The government should offer financial support for parents to encourage them to send their children to school this may help in improving the low rate enrollment in primary schooling in rural areas.

18. Moreover, some legislative measures should also be implemented to make it necessary for all the parents to complete the primary school education of their children.

\section{REFERENCES}

Aakvik, A., Salvanes, K. G., \& Vaage, K. (2005). Educational attainment and family background. German Economic Review, 6(3), 377-394.

Afzal, M., Malik, M. E., Begum, I., Sarwar, K., and Fatima, H. (2010). "Relationship among Education, Poverty and Economic Growth in Pakistan: An Econometric Analysis. J. Elementary Education" 22(1), 23-45.

Ahmad, I., Rauf, M., Rashid, A., Ur Rehman, S., \& Salam, M. (2013). Analysis of the problems of primary education system in Pakistan: Critical review of literature. Academic Research International, 4(2),324 


\section{International Journal of Social Science and Economic Research}

ISSN: $2455-8834$

Volume: 05, Issue: 07 "July 2020"

Aithal, P.S. and A. Shubhrajyotsna, (2016). Impact of on-line education on higher education system. International Journal of Engineering Research and Modern Education, 1(1): 225-235.

Alderman, Harold, Jere Behrman, Shahrukh Khan, David Ross, and Richard Sabot (1996). "Decomposing the Regional Gap in Cognitive Skills in Rural Pakistan "Journal of Asian Economics 7 (1):49-76.

Alderman, H., Orazem, P. F., and Paterno, E. M. (2001). "School quality, School Cost, and the Public/Private School Choices of Low-income Households in Pakistan. Journal of Human Resources, 304-326.

Ali, R. E. (1999). Determinants of Schooling in Rural Areas of Pakistan. The Lahore Journal of Economics, 99- 122.

Arif, G. M., Saqib, N., Zahid, G. M., and Khan, A. H. (1999). "Poverty, Gender, and Primary School Enrolment in Pakistan”. The Pakistan Development Review, 979-992.

Babatunde, M. A. \& Adefabi, R. A. (2005). Long run relationship between education and economic growth in Nigeria: Evidence from the Johansen's co integration approach. Paper presented at the regional conference on education in West Africa: Constraints and opportunities Dakar, Senegal, November 1st - 2nd, 2005. Cornell University / CREA / Ministèrede'Education du Sénégal.

Baluch, Mazhar ul Haq and Saima Shahid (2008). Determinants of Enrolment in Primary Education: A Case Study of District Lahore. Pakistan Economic and Social Review 46, 161-200.

Basilius, R.W. and A.G.A. Anak, (2017). Teachers' job satisfaction, organizational commitment, and performance in Indonesia: A study from Merauke District, Papua. International Journal of Development and Sustainability, 6(8): 700-711.

Becker, G.S. and Lewis, H.G.(1973). “Interaction between quantity and quality of children”,

Bokova, 2015. Education for all Global Monitoring Report. Paris: United Nations Educational Scientific and Cultural Organization.

Chaudhry, I. S., and Rahman, S. (2009). "The Impact of Gender Inequality in Education on Rural Poverty in Pakistan: An Empirical Analysis". European Journal of Economics, Finance and Administrative Sciences, 15, 174-188 
International Journal of Social Science and Economic Research

ISSN: $2455-8834$

Volume: 05, Issue: 07 "July 2020"

Editorial, T.E.T., (2013). Retrieved from https://tribune.com.pk/story/561967/survey-of-theeconomy-2012-13/.

Fabre, A. \& Augersaud-Veron, E. (2004). Education, poverty and child labour. Econometric Society 2004. Far Eastern Meetings 738, Econometric Society.

Federal Bureau of Statistics, (2011). "Pakistan Integrated Household Survey 2010-11", Islamabad, Government of Pakistan

Ghulam Farooque Laghari (2013). Critical Analysis of Primary Schools of Pakistan: A Survey of Sindh, USA, Interdisciplinary Journal of Contemporary Research in Business, March 2013.

Global, E. F. A. Overcoming inequality: why governance matters (2009). Government of Pakistan, Ministry of Education, National Education Policy, (2009).

Hameed-Ur-Rehman, M. and S.M.S. Sewani, (2013). Critical analysis of the educational policies of Pakistan. Dialogue (Pakistan), 8(3): 247-260.

Hamid, Shahnaz. (1993). A Micro Analysis of Demand-side Determinants of Schooling in Urban Pakistan. The Pakistan Development Review 32, 713-723.

Handa, S. (1999). Raising Primary School Enrollment in Developing Countries: The relative importance of Supply and Demand. International Food Policy Research Institute (No. 76). Discussion paper.

Heredia, E., O. (2007). The Impact of Education Decentralization on Education Output: A CrossCountry Study. Economics Dissertations. Paper 21. http://digitalarchive.gsu.edu/econ_diss/21

Karanu, Monicah, Hadija Murenga, and Joshia Osamba (2015). Socio-Cultural and Economic Factors affecting Primary School Enrolment in Baragoi Division of Samburu County, Kenya, Asian Journal of Management Sciences \& Education, Vol.4, 2.

Khuwaja, S., B.J. Selwyn and S.M. Shah, (2005). Prevalence and correlates of stunting among primary school children in rural areas of Southern Pakistan. Journal of Tropical Pediatrics, 51(2): 72-77

Krueger, A. B. \& Maleckova, J. (2003). Education, poverty and terrorism: Is there a causal connection? Journal of Economic Perspectives, 4(17), 119-144. 


\section{International Journal of Social Science and Economic Research}

ISSN: $2455-8834$

Volume: 05, Issue: 07 "July 2020"

Lynd, D., (2007). The education system in Pakistan: Assessment of the national education census. Islamabad: UNESCO, 25

Maitra, P. and Ranjan Ray (2002). The Joint Estimation of Child Participation in Schooling and Employment: Comparative Evidence from Three Continents. Oxford Development Studies 30, 41- 62 .

Majoka, M.I. and M.I. Khan, (2017). Education policy provisions and objectives. A review of Pakistani education policies. Italian Journal of Sociology of Education, 9(2): 104-125.

Memon, Ghulam Rasool (2007). Education in Pakistan: The Key Issues, Problems and the New Challenges. Journal of Management and Social Sciences 3, 47-55.

Moulton, J., (2001). Improving education in rural areas: Guidance for rural development specialists. The World Bank Report.

Nadeem A. Burney, M. I. (1995). Determinants of child school enrolment: evidence from LDCs using choice theoretic approach. International Journal of Social Economics, 24-40.

Njong, A. M. (2010). "The Effects of Educational Attainment on Poverty Reduction in Cameroon" Journal of Education Administration and Policy Studies, 2(1),001-008.

Pakistan social and living standards measurement survey (2005-06) National /Provincial. Pakistan Integrated Household Survey (1991). Dictionary of Variables for Community, Facility and Price surveys.

Pakistan Social and Living Standards Measurement Survey (2014-15).

Qureshi, M. G. (2012). The gender differences in school enrolment and returns to education in Pakistan. The Pakistan Development Review, 219-256.

Qureshi, M. Gohar, Saman Nazir, and Hafsa Hina (2014) Child Work and Schooling in Pakistan: To What Extent Poverty and Other Demographic and Parental Background Matter? Pakistan Institute of Development Economics, Islamabad. (PIDE Working Paper No. 105).

Ravallion, Martin and Quentin Wodon (2000). "Does Child Labour Displace Schooling? Evidence on Behavioral Responses to an Enrollment Subsidy" The Economic Journal 110. 
Shahid*, M. U. (2008). Determinants of Enrollment in Primary Education. A Case Study of District Lahore. Pakistan Economic and Social Review, 161-200.

Sathar, Zeba A., Asif Wazir, and Maqsood Sadiq (2013). Struggling against the Odds of Poverty, Access, and Gender: Secondary Schooling for Girls in Pakistan. The Lahore Journal of Economics 18: SE (September 2013), 67-92.

Toor, Imran Ashraf and Rizwana Parveen (2004). Factors Influencing Girl's Primary Enrolment in Pakistan. The Lahore Journal of Economics 9:2, 141-161

UNICEF, (1989). Convention on the Rights of the Child. Universal Primary Education (2015). A Chance for Every Child.

Wasti, S.E., 2012. Pakistan economic survey 2012-13. Retrieved from http://www.finance.gov.pk/survey_1213.html. 